\title{
Students' Metacognition and Personal Epistemology: View on Family
}

\section{Judy S. Tanael ${ }^{\mathrm{a}}$ and Maria Asuncion L. Magsino ${ }^{\mathrm{b}}$}

${ }^{a}$ College of Arts and Sciences, University of Asia and the Pacific, Pasig City, Philippines;

${ }^{b}$ College of Arts and Sciences, University of Asia and the Pacific, Pasig City, Philippines

*Corresponding author:

Judy S. Tanael

College of Arts and Sciences

University of Asia and the Pacific

Pasig City, Philippines

Email address: judy.tanael@uap.asia 


\title{
Students' Metacognition and Personal Epistemology: View on Family
}

\begin{abstract}
Personal epistemology refers to personal theories of knowledge and how knowledge is justified. The trajectory of intellectual and moral development proceeds in three major stages. Firstly, simplistic or black and white thinking; secondly, relativistic thinking which considers different perspectives as equally valid; and finally, the attainment of evaluative thinking, which is characterized by a commitment to a particular standpoint that organizes other possible perspectives. Apart from these developmental characteristics, current studies have emphasized the multi-dimensionality of personal epistemology. Recently, as these two features have become reconciled, proponents have stressed the need to relate epistemological development to constructs such as metacognition, which is deemed a pre-requisite for epistemological sophistication. In response to the need for concurrently studying metacognition and personal epistemology, this study investigates the dimensions of personal epistemology and metacognition of students on a philosophy course about the family offered within a liberal education program at a University in Metro Manila, Philippines. There were at least 13 respondents who enrolled during the second semester of school year 2017-2018. The study utilized pre- and post-test course evaluations to measure the students' metacognitive level. Reported changes versus the actual discrepant answers were then compared and the results tabulated. The study also used an actual assessment of students' learning to measure dimensions of personal epistemology. The students' reasoning in the final exam, which required them to express their personal beliefs or manifesto, was thematically analyzed using the personal epistemology dimensions' framework, tabulated, and then compared with their other scores. The results suggested that most students (11 out of 13) failed to identify the exact topics or issues where their views had changed. However, the students' awareness of their changing views about selected topics could serve as an indicator of the magnitude of their learning. Some of these students even declared a personal commitment to transcendent values; which suggested that they had reached the most sophisticated level of personal epistemology through taking the course.
\end{abstract}

Keywords: personal epistemology, metacognition, assessment of students' learning

\section{Introduction}

Personal epistemology refers to personal theories of knowledge, and how knowledge is justified. The seminal work in personal epistemology was the longitudinal study conducted by Perry (1968) which presented the abstracted intellectual and ethical trajectory of liberal arts college students who were interviewed from their freshmen to their senior year. The trajectory of intellectual and moral development progressed in three major stages; firstly, simplistic or black and white thinking and reasoning; secondly, relativistic thinking where even opposing views are considered equally valid; and finally, the attainment of evaluative thinking, which is characterized by commitment to a particular standpoint that acts as a lens to order or organize other perspectives. 
A number of research studies have investigated epistemological beliefs (Kuhn, 2000; Baxter, 2001; King and Kitchener, 2004), most of which have been longitudinal studies, and have validated the generalized scheme of Perry's model. These studies, which spanned decades and investigated a variety of respondents, concur that very few individuals, even among the highly educated, have reached the most advanced level of the trajectory. In other words, very few individuals attain an evaluative mindset that is capable of considering different perspectives, and at the same time maintaining a firm and explicit standpoint. Due to these findings, there has been an insistent call to include epistemological sophistication as an educational goal (Kuhn, 2000; King \& Kitchener, 2004; Hofer, 2004).

Apart from these developmental characteristics, current personal epistemology studies have emphasized the domain-specificity and multi-dimensionality of the construct. Dimensions of personal epistemology include the following: (a) justification by authority; reference to and reliance on testimonies, teachings and assertions of persons respected for establishing validity and truth; (b) personal justification; reliance on and drawing from one's logic, knowledge, and experiences to establish validity or truth; and, (c) simple and certain knowledge; the degree of perceived simplicity or complexity of the body of knowledge based on the existence of multiple views, and a broad range or area of study, as well as certainty and uncertainty based on changing nature, practice, and innovation (adapted from Greene, 2007). In addition, when the developmental and multi-dimensional features of personal epistemology are reconciled, proponents such as Schommer-Aikins (2004) and Hofer (2004) have both stressed the importance of relating epistemological development to other constructs, such as metacognition, or knowing how one knows, which are deemed a pre-requisite for epistemological sophistication.

Instead of direct measures through questionnaires, which is one of the most popular and convenient research instruments, the current study used the actual assessment of students' learning in a specific philosophy course on the family to measure students' growth in personal epistemology. The current study therefore used indirect measures of personal epistemology and extracted them from the students' outcomes and personal reasoning in a specific course. The study also utilized pre- and post-test course evaluations to measure students' metacognitive level through students' monitoring of their understanding of concepts or course content. The study then provides groundwork for authentic evaluation of students' current level of epistemological sophistication, which is a gap in the literature, and, at the same time, establishes students' metacognitive level. In addition, students' metacognitive levels and epistemological levels were linked to their final academic performance.

\section{Methodology}

This study was exploratory in nature, and investigated dimensions of personal epistemology as well as the metacognitive assessment of students on a philosophy course on the family, which is a core subject in a liberal education program offered at a University in Metro Manila, Philippines. The philosophy subject was described as a preparatory course on marriage and family life. The course clarifies the nature, properties, and the goals of family life as a 
metaphysical reality. On the practical side, the course investigates and evaluates the state of interpersonal relationships in relation to marriage and the family, as well as popular notions and beliefs about these institutions in contemporary culture. Given that the specific philosophical subject, and metacognition, as well as personal epistemology were the constructs under study, the specific research questions were: (1) how accurate are selected college students' perceptions of changes in their own answers to selected topics on marriage and the family? Next, (2) using the dimensions of personal epistemology, what are the patterns in a) the students reasoning and b) the students' final performance?

The respondents to the study were students enrolled in a philosophy course on the family at a university in Metro Manila during the second semester of school year 2017-2018. There were at least 13 respondents with complete answers for the metacognitive component, who answered an online survey near the beginning and at the end of the course about their views on selected marriage and family issues. The survey served as pre-test and post-test evaluation. During the post-test, students were also asked to identify how they had changed their views, and in which areas. All the questions and responses were delivered through Google Forms and Google Docs. The accuracy and perceived magnitude of change in views were considered indicators of metacognitive awareness.

Personal epistemology, on the other hand, was extracted from the students' reasoning during the final unit test or exam, which required them to express their personal beliefs or manifesto. Using the dimensions of personal epistemology as criteria, individual students' answers were categorized by an educational psychologist who has worked on personal epistemology for several years. Emerging patterns were extrapolated from the individual students' responses by comparing and contrasting them according to the following dimensions; justification by authority (references used in class, authors and philosophers) and personal justification (experiences, own reasoning and observation). Finally, a personal epistemology profile of each student was compared to their individual scores to determine if there were any emergent patterns or relationships.

To assess metacognitive functioning, during the pre-test, students were asked about their views of various family issues such as: a) if marriage is a better option than staying single on a longterm basis; b) if there are more long-term marriages in recent years than in the past; $c$ ) if marriage and family necessarily come together; d) if the students describe their views as liberal, relative, traditional, or other. The same questions were asked during the post-test, as well as their personal explanations of their views, and identification of aspects of the class which contributed to their views. The main metacognitive question, however, involved the item asking students to identify the items where their answers changed. An example answer was: "I changed my answers in item numbers 6 and 9" (student A).

The analysis involved firstly comparing the pre-test and post-test answers, and then identifying the accuracy of the answer as well as the magnitude of change. For example, in student A's answer, only one item was accurate (the student changed her answer to item number 9, and also item numbers 4 and 5), but the student perceived less change, since she perceived change in 
only two items numbers (6 and 9); whereas her responses changed in answer to three items (specifically 4, 5, and 9). A comparison of pre-test and post-test responses was conducted for each student. The categories for metacognitive levels were assigned as high, mid, and low. An example of high metacognitive level was high accuracy (where the student perceived changing his/her mind about items that matched the item number/s as identified by the pre-test and posttest, e.g., item numbers 4, 6, and 9) and exact magnitude (the number of items where the student changed his/her mind was the same for perceived and actual e.g., 3 items). Higher metacognitive development was also indicated when the student perceived more changes than were the case, since the student possibly perceived a change, although not necessarily to their views, but more to their level of articulation, which was correlated later on with their reasoning/manifesto in the final exam. A mid metacognitive level was characterized as having high rating on one of the two criteria, either accuracy or magnitude; and a low metacognitive level was assigned when the rating was mid to low in the two criteria. Student A's response for example, with only one accurate answer and who perceived less than the actual change, was categorized as a low level of metacognitive awareness. (Please see Appendix A for the data on metacognitive awareness and the assigned level).

Personal epistemology, on the other hand, was extracted from students' responses to the final exam. Specifically, they were given a diagram which encapsulated the major concepts in the course and asked to write their six (6) point manifesto expressing their personal beliefs in relation to the diagram. Please see Appendix B for the final exam question and Appendix $\mathrm{C}$ for a sample student's answer to the exam. During the analysis, the justifications provided in the essay were classified as justification by authority (JA) and personal justification (PJ). Examples of JA were explicit references to authors used in class (e.g., Aristotle, Wojtyla, C. S. Lewis), mentioning class discussions, and other concepts such as truth or nature, which the student presented as an authority. PJs, on the other hand, were those that were primarily characterized by logical reasoning, which has been arrived at personally by the student, as well as expressions or appeals to one's subjective or personal beliefs. The answers were assessed using a rubric, which is presented as Appendix C.

In essence, the students' responses were tabulated, compared and contrasted, and themes were extracted from the responses to answer the research questions focusing on (1) students' level of metacognitive awareness and (2) the students' justifications of personal beliefs; which together were considered indicators of personal epistemological development. A summarized comparison table of the data on metacognitive awareness, personal epistemology, and student performance in the final exam are presented in Appendix A.

\section{Results}

The results suggested that one aspect of metacognition; monitoring of knowledge, which in this study was specific to changes in students' views on selected topics, could be an indicator of actual students' learning. In this study, two aspects of metacognitive awareness were considered; accuracy and magnitude. The accuracy of metacognition referred to awareness of the exact items where students had changed their views, whereas the magnitude of metacognitive awareness referred to awareness of the number of items perceived, compared to 
the actual number of items where students had changed their views. The specific finding was that most students failed to identify the exact topics or issues where they had changed their minds. Only two students out of 13 with complete pre and post data on metacognitive awareness were accurate at determining the issues where they had changed their views. The other finding on the magnitude of metacognitive awareness indicated that three students who perceived more changes relative to their initial views were among the students who garnered high scores. On the other hand, three students who perceived less change than their actual answers were among the low scorers. Combining the trend for high scorers (more perceived change) and low scorers (less perceived change) this finding seems to suggest that the perceived magnitude of change (more or less than actual) could refer to changes in the clarity of students' understanding of specific issues (more perceived change for high scores; low perceived change for low scorers) but not necessarily refer to changes in position relative to issues on the family (accurate metacognitive awareness). Furthermore, the other four students with higher scores perceived the correct number of items where their views had changed but the items identified were not accurate. Although not completely accurate, they had some degree of metacognitive awareness.

The question about classifying students' reasoning using dimensions of personal epistemology found that students with more sophisticated personal epistemologies, who provided stronger justifications by authority, and gave PJs based on logical reasoning, got higher scores in the final test. Some of these students even declared a personal commitment to transcendent values.

Responses exhibiting strong justifications by authority included: properly cited and identified references and authors; explicitly stated truths; and legal and ecclesiastical pronouncements. Strong PJs included the following: logical conclusions or reasoning that expounded on the consequences of going against human nature; personal realizations of purpose in life as well as the existence of family life; realization of the interconnectedness between the concepts of the person, family, and marriage, while at the same time, perceiving the boundaries that exist between them. Few students possessed the conviction that the nature of the person and natural institutions transcend the passing of time and differences in culture.

On the other hand, students who got lower scores exhibited a less sophisticated personal epistemology, for example, by relying more on class discussions, what the law states, or what tradition and church observe. There was one case where personal experience was treated as a source of authority.

Interestingly, what added complexity to the subject matter were students' personal issues, which could be either facilitators of learning, or barriers that lead to confusion and conflicting ideas expressed in students' final exam papers. Examples of these personal issues or cases were 1) curtailed personal freedom by parents; 2) social media bullying; and, 3) being raised by a single parent. Those who had not reached resolutions (first and second cases) expressed conflicting views until the end of the course, while one student (third case) who had acknowledged the difference between personal circumstances, the "ideal" nature of the family, and had reconciled these differences, reached an understanding of the transcendence of the person and institutions, and even made a personal commitment to uphold transcendental values. 
This was an interesting result, which runs parallel to the paths drawn by Perry in his seminal work from the 1970s. In Perry's study students who had experienced similar confusing or challenging situations either regressed or progressed along the trajectory of intellectual and moral development. In the future, assessment design and results could perhaps be utilized to identify and to provide timely support or "caffolding" for those who may not be progressing.

\section{Conclusion and Recommendation}

In conclusion, this study has provided qualitative evidence that students who reached a level of committed personal epistemology in relation to a philosophy course on family, tended to have awareness of the change in their perspective. They also had higher assessment scores. However, students who remained at a more simplistic level of reasoning tended to be less metacognitively aware, were unable to perceive changes in their perspective, and also had lower academic assessment scores. Additionally, this research has the potential to help uncover the barriers and enablers specific to the subject of the philosophy of the family, where the personal experiences of students vary, and where personal issues often act as a barrier or enabler to understanding the concepts relevant to the course. These findings confirmed that the personal epistemology of students at the tertiary level of education is indeed malleable. With the philosophical training offered by this course as a personal development intervention, students can become increasingly sophisticated in their personal epistemology.

The use of learning assessment results to determine dimensions of students' personal epistemology, and the use of reflective pre and post-course evaluation results to assess students' metacognitive awareness levels, added value to the measurement of the development of practical epistemologies. Higher education institutions and different programs in particular domains could adopt a similar measurement method and design. The results of future studies have the potential to provide domain-specific teaching tools to explicitly enhance students' repertoire of metacognitive and epistemic strategies.

Finally, this study recommends investigating the changing personal epistemologies recorded in students' exams and at the same time, analyzing students' metacognitive level through reflective pre- and post-course evaluation. The quantitative correlation of the two constructs not only in philosophy courses, but in other subjects that require students to reason explicitly; alongside students' academic performance measured by test scores and other class requirements; is likewise recommended to test the generalizability of these results.

\section{References}

Alpaslan, M. M., Yalvac, B., \& Willson, V. (2017). A Meta Analytical Review of the Relationship between Personal Epistemology and Self-Regulated Learning. Turkish Journal of Education, 6(2), 648-667. Retrieved from https://eric.ed.gov/contentdelivery/servlet/ERICServlet?accno=ED577163

Barger, M. M., Wormington, S. V., Huettel, L. G., \& Linnenbrink-Garcia, L. (2016). Developmental changes in college engineering students' personal epistemology profiles. Learning and Individual Differences, 48 , $1-8$. 
Baxter, M. M. (2001). A constructive revision of the Measure of Epistemological Reflection. Journal of College Student Development, 42(6).

Brownlee, J., Walker, S., Lennox, S., Exley, B., \& Pearce, S. (2009). The first year university experience: using personal epistemology to understand effective learning and teaching in higher education. Higher Education, 58(5), 599-618.

Flavell, J. H. (1979). Metacognition and cognitive monitoring: A new area of cognitive-developmental inquiry. American Psychologist, 34(10), 906-911.

Greene, J. A. (2007). A model of the development of epistemic and ontologic cognition (Doctoral dissertation). College Park, MD: University of Maryland.

Hofer, B. K. (2004). Epistemological understanding as a metacognitive process: Thinking aloud during online searching. Educational Psychologist, 39, 43-55. Retrieved from EBSCOhost.

Hofer, B. K. (2008). Epistemological Development. The Gale Group-Education. Com. Retrieved from http://www.education.com/reference/article/epistemological-development/

King, P. M., \& Kitchener, K. S. (2004). Reflective judgment: Theory and research on the development of epistemic assumptions through adulthood. Educational psychologist, 39, 5-18.

Kuhn, D. (2000). Metacognitive development. Current directions in psychological science, 9(5), 178-181.

Lukie, M. P. (2015). Fostering student metacognition and personal epistemology in the physics classroom through the pedagogical use of mnemonic strategies. Alberta Science Education Journal, 44(1), 25-31.

Perry Jr, W. G. (1968). Patterns of development in thought and values of students in a liberal arts college: A validation of a scheme. Final Report.

Schommer-Aikins, M. (2004). Explaining the epistemological belief system: Introducing the embedded systemic model and coordinated research approach. Educational psychologist, 39, 19-29. 


\section{APPENDIX A. Comparison Table of Data on Metacognitive Awareness, Summary of Personal Epistemology, and Final Exam Grade}

\begin{tabular}{|c|c|c|c|}
\hline $\begin{array}{l}\text { Student } \\
\text { Code }\end{array}$ & Metacognitive awareness & Summary Personal Epistemology & $\begin{array}{l}\text { Final } \\
\text { Exam } \\
\text { Grade }\end{array}$ \\
\hline A & $\begin{array}{l}1 \text { accurate answer, } \\
\text { perceived less change } \\
\text { than actual }(-1)(\mathrm{MID})\end{array}$ & $\begin{array}{l}\text { JA } 4 \text { (class discussion, PJ }-2 \text { ) } \\
\text { (agreement with personal view, } \\
\text { personal interview) }\end{array}$ & 85 \\
\hline B & $\begin{array}{l}1 \text { accurate answer, } \\
\text { perceived } 3 \text { changes, but } \\
\text { not exact items (MID) }\end{array}$ & $\begin{array}{l}\text { JA } 2 \text { (report, St. Paul); PJ (family, } \\
\text { experience, choice) = explicit } \\
\text { commitment from combined JA \& PJ }\end{array}$ & 94 \\
\hline $\mathrm{C}$ & $\begin{array}{l}\text { perceived } 3 \text { changes, but } \\
\text { not exact items }\end{array}$ & no final exam & $\begin{array}{l}\text { no final } \\
\text { exam }\end{array}$ \\
\hline $\mathrm{D}$ & Accurate $(\mathrm{HIGH})$ & $\begin{array}{l}\text { JA } 2 \text {-- Law, church, class discussion; } \\
\text { PJ --family environment, personal } \\
\text { definition, other personal factors-- } \\
\text { social media bullying, friends = } \\
\text { conflicting ideas }\end{array}$ & 84 \\
\hline $\mathrm{E}$ & Accurate $(\mathrm{HIGH})$ & $\begin{array}{l}\text { JA } 3 \text {-- man's nature, } 4 \text { causes, Wojtyla, } \\
\text { PJ -logic \& reasoning (derivation \& } \\
\text { necessity), personal realization; PJ and } \\
\text { JA combined but differentiated or } \\
\text { effectively used both, but clarifies the } \\
\text { boundaries and relationship of the two }\end{array}$ & 96 \\
\hline $\mathrm{F}$ & $\begin{array}{l}\text { perceived fewer than } \\
\text { actual changes }(-2) \text { not } \\
\text { exact items (LOW) }\end{array}$ & $\begin{array}{l}\text { Fused JA and PJ -- unprocessed } \\
\text { experience taken as authority }\end{array}$ & 85 \\
\hline $\mathrm{G}$ & $\begin{array}{l}2 \text { accurate answers (items } \\
2 \& \text { \&) but perceived } \\
\text { fewer than actual changes } \\
(-1)(\mathrm{LOW})\end{array}$ & JA -- knowledge from class -- & 85 \\
\hline $\mathrm{H}$ & $\begin{array}{l}1 \text { accurate change, } \\
\text { perceived more than } \\
\text { actual changes }(+8)(\mathrm{MID} \\
\text { to high) }\end{array}$ & $\begin{array}{l}\text { JA -- Aristotle, philosophy, class } \\
\text { lessons; PJ -- reasoning with } \\
\text { consequences, self-realization of } \\
\text { personal purpose, PJ \& JA knowledge } \\
\text { of interconnectedness and boundaries; } \\
\text { transcendence -- persons and time }\end{array}$ & 99 \\
\hline $\mathrm{I}$ & $\begin{array}{l}1 \text { accurate answer, } \\
\text { perceived less change } \\
\text { than actual }(-3)(\mathrm{MID})\end{array}$ & $\begin{array}{l}\text { JA -- CS Lewis, customary definition, } \\
\text { defining principles; PJ --inferring } \\
\text { relationships \& consequences, relating } \\
\text { ideas, self-realization, despite family } \\
\text { background (raised by solo parent); PJ } \\
\& \text { JA -- interconnection, transcending } \\
\text { culture and time, basic principles and } \\
\text { personal realization }\end{array}$ & 92 \\
\hline $\mathrm{J}$ & $\begin{array}{l}1 \text { accurate answer, } \\
\text { perceived more than } \\
\text { actual changes }(+2)(\mathrm{MID} \\
\text { to high) }\end{array}$ & $\begin{array}{l}\text { JA -- truth, class discussion, nature, PJ } \\
\text {--own decision-project, personal belief, } \\
\text { reasoning by pointing out } \\
\text { consequences }\end{array}$ & 95 \\
\hline
\end{tabular}




\begin{tabular}{|c|c|c|c|}
\hline $\mathrm{K}$ & $\begin{array}{l}1 \text { accurate answer, } \\
\text { perceived } 3 \text { changes but } \\
\text { not exact items (MID) }\end{array}$ & $\begin{array}{l}\text { JA -- tradition, nature/cause, good \& } \\
\text { truth; PJ --personal opinion, self- } \\
\text { realization }\end{array}$ & 90 \\
\hline $\mathrm{L}$ & $\begin{array}{l}\text { perceived } 1 \text { change, not } \\
\text { exact item (MID) }\end{array}$ & $\begin{array}{l}\text { JA --truth, Aristotle, nature of man, JP } \\
\text { II, church and God; PJ - personal belief, } \\
\text { reasoning against popular/changing } \\
\text { view--valuing consequences which } \\
\text { referred to the acquisition of virtues, } \\
\text { personal commitment }\end{array}$ & 96 \\
\hline $\mathrm{M}$ & $\begin{array}{l}\text { perceived more change } \\
\text { than actual }(+2)(\mathrm{MID})\end{array}$ & $\begin{array}{l}\text { JA -- Aristotle, K. Wojtyla; PJ -- } \\
\text { reasoning, personal understanding }\end{array}$ & 90 \\
\hline $\mathrm{N}$ & $\begin{array}{l}\text { incomplete data, no pre- } \\
\text { test }\end{array}$ & $\begin{array}{l}\text { with personal issue of freedom --JA-- } \\
\text { parents, CS Lewis, PJ -- reasoning - } \\
\text { states pre-requisite--> knowledge of } \\
\text { real good, consequence->lack of self- } \\
\text { giving; }\end{array}$ & 82 \\
\hline $\mathrm{O}$ & $\begin{array}{l}\text { incomplete data, no post- } \\
\text { test }\end{array}$ & $\begin{array}{l}\text { JA -- Aristotle, CS Lewis, Wojtyla; PJ } \\
\text {--reasoning -> importance of parents' } \\
\text { role, deduced needs of man as a social } \\
\text { being, choice as a consequence of } \\
\text { man's freedom; consequences of family } \\
\text { life for society }\end{array}$ & 95 \\
\hline
\end{tabular}




\section{APPENDIX B. Final Exam and Diagram of the Family}

Making use of the diagram given below as your framework,

a. Write a six (6) point MANIFESTO expressing the beliefs you have formulated in relation to each of the items in the diagram;

b. Expound on the basis for these beliefs by giving an explanation of what the diagram means to you;

c. Then, using one of the issues reported in class (except your own), explain how contemporary culture is contributing to the deinstitutionalization of marriage and family. Please write the title of the report of your choice in space provided.

DIAGRAM OF FAMILY COURSE:
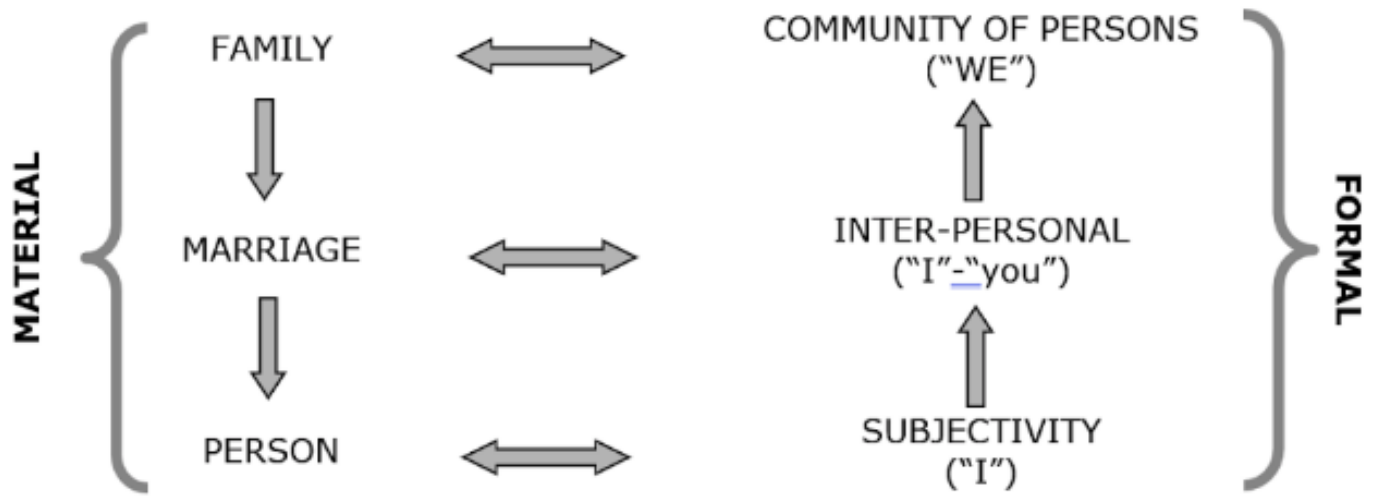


\section{APPENDIX C. Sample Student's Answer}

According to Aristotelian metaphysics, there are four causes of how a being comes to be. These four causes include the material, formal, efficient, and final cause. In the context of Aristotelian metaphysics, the material cause of something refers to its physical properties or makeup. This is what can be seen in the outside world of persons. On the other hand, the formal cause refers to the structure of something or the direction it leads to.

For the first point of my manifesto, I have said this in relation to the material cause of a person which is the body. Since the body is the material cause of a person and since each person has human dignity, it is just right that this is to be upheld in all ways. To respect the body means to acknowledge that it exists as part of a person, and that it is to be respected in ways that would give purpose for the good of the person.

For the second point of my manifesto, I have pointed out that marriage is strictly between man and woman which justifies the material cause of marriage. The material cause of marriage refers to the living bodies of man and woman over which they acquire mutual rights. The difference brought about by sexuality is the cause to marriage and family. Sexuality cannot be understood fully if taken out of the context of marriage and family.

For the third point of my manifesto, I have said this in relation to what the material cause of a family is. The material cause of family refers to man and woman including the children brought about by conjugal union. Having this relation as the material cause means that my biological family will always and forever be my family in the sense that I cannot run away from them and my personal identity will always be associated with them. Because of this relation, it is proper that I abide by loving ways bounded by the connection we have as interrelated persons.

For the fourth point of my manifesto, I have pointed this out in relation to my subjectivity as a person. Since the formal cause of the person is the soul, this implies that each person is an objective entity which as a definite subject has the closest contact with the whole external world and is most intimately involved with it, precisely because of its inwardness, its interior life.

For the fifth point of my manifesto, I have said this in relation to the formal cause of marriage. The formal cause of marriage is the love expressed in mutual self-giving intended to never be withdrawn. It is interpersonal because it is a strong, deep, or close association between two people.

For the sixth point of my manifesto, I have pointed this out in relation to the formal cause of family. The formal cause of family is the love embodied in the relations which are present within the family which are the conjugal, parental-filial, and fraternal relationships.

To relate all of this together, it would be easier to explain in a chronological flow. Each person being his/her body as the material cause, has his/her own individual subjectivity, which means that one has the freedom to either accept or reject another person. This acceptance of another can eventually lead to marriage which has man and woman as the material causes. This marriage involves intersubjectivity between two persons bounded by conjugal union, which implies that the husband and wife become one and share a deep and personal connection with each other. After marriage, comes family. The material cause of family would be husband, wife, and children, and the formality of these would mean the love embodied within those relations. Being a social unit, the family becomes a form of community or a "we" where a structure is made enabling each member to become persons, both as individual and social 
beings. The family is that form of structure where a human being is humanized and socialized. This is where the development of the individual starts. Combining all individuals in a community from each family would be a reflection of the development of the whole society.

In the report, "A Speculative Study on the Implications of Civil Unions toward National Economies," it was mentioned that the arguments for civil unions to be legalized consisted of the following: all love between all persons is equal, marriage is a human right, human rights apply to all human beings, there is a denial of equality, denying some people the option to marry is discriminatory, and that gay couples make good parents. These arguments mentioned in the report to legalize civil unions all invalidate the casualties of marriage -- especially the purpose of marriage and family. First of all, the material cause of marriage would be the living bodies of man and woman over which they acquire mutual rights. This already denies the innateness that marriage is supposed to possess in civil unions. Man and woman were made for each other and can already be seen in the complementariness of male and female. The second causality that civil unions would be invaliding would be the material cause of families which are man, wife, and the children generated within that union. Civil unions most importantly invalidate the purpose of sexuality in which we are all innate. The expression of sexuality would only be to get married and build a family. This is the reason as to why marriage exists in the first place, to build communities composed of persons from biological families where they were formed to become capable individuals. Civil unions should be invalid not only because they invalidate metaphysics itself, but because it goes against what is innate in human persons. Going against this innateness degrades the human dignity of the two people involved within the civil union; therefore, it is wrong.

All of these lessons in family class have aided me toward realizing the purpose of myself as a person, marriage, and family. Family has made me realize that these three things are all connected, in a way that there are also boundaries as to what and what should not be done. Before entering family class, I was all for the liberal movement where people had the right to decide what they want. After the course, I am now able to realize the value of each person and how to live out that value in the right way eventually through marriage. Family has most importantly made me realize of the importance and significance of marriage. It taught me that the purpose of marriage would have to be family building, leading to forming communities and societies which reflect in them the love encompassed in each household. (Student $\mathrm{H}$ ) 


\section{APPENDIX D. Rubric}

Rubrics for grading

\begin{tabular}{|c|c|c|c|}
\hline \multirow{4}{*}{$\begin{array}{l}\mathbf{C} \\
\mathbf{O} \\
\mathbf{N} \\
\mathbf{T} \\
\mathbf{E} \\
\mathbf{N} \\
\mathbf{T} \\
50 \%\end{array}$} & $\begin{array}{l}\text { Accurate presentation of concepts \& principles, } \\
\text { clear definitions of terms when needed with } \\
\text { precision in use of terminology. Demonstrates a } \\
\text { sound grasp of issues and ideas. }\end{array}$ & 10 & $\begin{array}{l}\text { Remarks } \\
\text { (sample only) }\end{array}$ \\
\hline & $\begin{array}{l}\text { Mostly accurate with few errors \&/or } \\
\text { inconsistencies of information. Use of } \\
\text { terminology satisfactory. Grasp of ideas and } \\
\text { issues convincing. }\end{array}$ & 9 & \multirow{3}{*}{$\begin{array}{l}\text { I credit your essay for clarity } \\
\text { in the exposition of concepts } \\
\text { and ideas. } \\
\text { I raised a question about why } \\
\text { biological families and no } \\
\text { other forms should be } \\
\text { emphasized as you claim. Just } \\
\text { to COMPLETE the argument. }\end{array}$} \\
\hline & $\begin{array}{l}\text { Some inconsistencies and errors, with clarity of } \\
\text { language sometimes compromised. Issues and } \\
\text { ideas expressed tentatively. }\end{array}$ & 8 & \\
\hline & $\begin{array}{l}\text { Mostly inaccurate with little evidence of } \\
\text { awareness of ideas or issues attempted. }\end{array}$ & 7 & \\
\hline \multirow{4}{*}{$\begin{array}{l}\mathbf{O} \\
\mathbf{r} \\
\mathbf{g} \\
\mathbf{a} \\
\mathbf{n} \\
\mathbf{i} \\
\mathbf{z} \\
\mathbf{a} \\
\mathbf{t} \\
\mathbf{i} \\
\mathbf{o} \\
\mathbf{n} \\
40 \%\end{array}$} & $\begin{array}{l}\text { Essay easy to follow \& understand, with ideas } \\
\text { that flowed logically from one to the next with } \\
\text { excellent transitions. Addressed all questions in } \\
\text { a logical, coherent, and insightful manner, with } \\
\text { equal weight given to questions. Issues tackled } \\
\text { in appropriate depth. }\end{array}$ & 10 & \multirow[t]{4}{*}{$\begin{array}{l}\text { Excellent organization. } \\
\text { Logical flow and very easy to } \\
\text { follow. }\end{array}$} \\
\hline & $\begin{array}{l}\text { Most questions were evenly and logically } \\
\text { addressed. Clarity of ideas with transitions } \\
\text { satisfactory. Reflection on issues evident. }\end{array}$ & 9 & \\
\hline & $\begin{array}{l}\text { Addressed some questions in an understandable } \\
\text { and logical format. Some hitches in the flow } \\
\text { \&/or transitions were sparse. }\end{array}$ & 8 & \\
\hline & $\begin{array}{l}\text { Choppy and confusing, difficult to follow. } \\
\text { Transitions missing and questions from syllabus } \\
\text { ignored. }\end{array}$ & 7 & \\
\hline \multirow{3}{*}{$\begin{array}{l}\text { M } \\
\text { e } \\
\text { c } \\
\text { h } \\
\text { a } \\
\text { n } \\
\text { i } \\
\text { c } \\
\text { s } \\
10 \%\end{array}$} & $\begin{array}{l}\text { Few or no errors in grammar, use of words, } \\
\text { spelling, punctuation, etc. Paragraphs properly } \\
\text { delineated. }\end{array}$ & 10 & \multirow{3}{*}{$\begin{array}{l}\text { Important citation missed out, } \\
\text { inaccurate use of verb } \\
\text { BOUND, some awkward } \\
\text { phrases... }\end{array}$} \\
\hline & $\begin{array}{l}\text { Few mechanical \&/or technical errors with only } \\
\text { slight deviations in division of ideas into } \\
\text { paragraphs. }\end{array}$ & 9 & \\
\hline & $\begin{array}{l}\text { Mechanical \&/or technical errors notable with } \\
\text { lack of attention to rules of composition \& } \\
\text { neatness. }\end{array}$ & 8 & \\
\hline
\end{tabular}




\begin{tabular}{|l|l|l|l|}
\hline In need of complete overhaul. & 7 & \\
\hline
\end{tabular}

